\title{
Virulence Composition of Phytophthora sojae in Michigan
}

\author{
R. C. Kaitany, Research Associate, and L. P. Hart, Professor and Acting Director, Center for Integrated Plant Sys- \\ tems, Michigan State University, East Lansing 48824; and G. R. Safir, Professor, Department of Plant Pathology, \\ Michigan State University, East Lansing 48824
}

\begin{abstract}
Kaitany, R. C., Hart, L. P., and Safir, G. R. 2001. Virulence composition of Phytophthora sojae in Michigan. Plant Dis. 85:1103-1106.

Knowing the virulence composition of Phytophthora sojae is important for the management of Phytophthora root and stem rot of soybean. Plant samples were collected in Michigan from diseased plants in soybean fields with Phytophthora root and stem rot symptoms. Eighty-seven isolates of $P$. sojae were evaluated for virulence using 13 differential soybean cultivars. Rps $3 b$, $3 a, 1 b, 1 k$, and 6 were resistant to $81,77,74,69$, and $66 \%$ of the isolates, respectively, while Rps $1 a$ and 7 were resistant to only 12 to $13 \%$ of the isolates. Races 2, 25, 41, and 44 of P. sojae were identified among the isolates and reported for the first time in Michigan. Virulence formulae of 69 isolates did not match those of currently known races of $P$. sojae. Nine isolates were considered nonpathogenic. Incorporating $R p s$ genes $1 b, 1 k, 3 a, 3 b$, and 6 in soybean cultivars with good field tolerance, in conjunction with other control measures, should offer improved protection of soybeans from Phytophthora root and stem rot in Michigan.
\end{abstract}

Monitoring the race or virulence structure of a pathogen population is a key component in any management program using specific resistance (complete suppression of growth of a given pathogen by a cultivar). Race specific resistance has been a major element in the control of Phytophthora root rot (23). However, the appearance of new virulent races in response to continued use of resistant cultivars has led to documented failures of race specific resistance (25). Phytophthora sojae isolates are characterized to race using the hypocotyl inoculation method and differential reactions of soybean lines with 13 resistance genes at 7 loci (28). Breeders try to incorporate resistance to the most important races in their areas, if that knowledge and resistant germ plasm are available.

Other tactics used to control Phytophthora root rot have included tolerance (field resistance), fungicides (primarily metalaxyl), and cultural practices such as moldboard plowing and tile drainage. None of these have proved to be entirely effective by themselves (25). Based on this observation, Schmitthenner and Van Doren (25) advocated an integrated pest management (IPM) approach to control Phytophthora root rot. Availability of resistant cultivars and knowledge of the virulence structure of the pathogen in the target area

Corresponding author: Gene R. Safir

E-mail: safir@msu.edu

Accepted for publication 20 June 2001.

Publication no. D-2001-0723-05R

(C) 2001 The American Phytopathological Society is vital if specific resistance is going to be an effective component of an IPM program.

Although soybeans grown in Michigan have been relatively free from Phytophthora root rot, the potential to affect yield exists. Lockwood and Chen (15) isolated races $1,3,4$, and 6 of $P$. sojae and demonstrated the involvement of $P$. sojae in the root rot complex of soybeans in Michigan. Presently, information on the virulence structure of $P$. sojae and the occurrence and potential impact of Phytophthora root rot in Michigan soybean fields is not sufficient for farmers to make informed decisions when selecting cultivars. The objective of this project was to determine the virulence characteristics of $P$. sojae in Michigan.

\section{MATERIALS AND METHODS}

Collection of samples. Plant samples were collected from 60 soybean fields in 10 Michigan counties from 1993 to 1997. Soybean fields were walked in a zigzag pattern, and one to five samples per field were collected when symptomatic plants were found. Five to 10 plants collected at any one point in a single field constituted a sample. Plants were placed in plastic bags and stored for a maximum of 3 months at $5^{\circ} \mathrm{C}$ to maintain pathogen viability as samples were being processed. $P$. sojae races 1 , $3,4,7$, and 25 , and differential soybean cultivars (Harlon Rps1-a, Harosoy 13xx Rps1-b, Williams 79 Rps1-c, PI 103 Rps1d, Williams 82 Rps1-k, L76-1988 Rps2, L83-570 Rps3-a, PRX-146-36 Rps3-b, PRX145-48 Rps3-c, L85-2352 Rps4, L853059 Rps5, Harosoy 62xx Rps6, Harosoy Rps7, and Williams rps) representing different $R p s$ genes and alleles were provided by A. F. Schmitthenner of Ohio State University.

Isolation from diseased soybean plants. The Canaday-Schmitthenner medium (5) without hymexizol (which has the potential to inhibit sensitive strains of Phytophthora) was used to isolate Phytophthora from plant samples. Stems and roots of plants with well-defined symptoms were disinfected with $10 \%$ bleach for 10 min and thoroughly rinsed three to four times with sterile distilled water. Small sections of tissue were taken from the edges of advancing lesions and placed on the isolation medium in $100 \times 15 \mathrm{~mm}$ petri plates. Necrotic tissue also was removed from plants with severe flood damage (following heavy rainfall), surface sterilized, rinsed, and placed on the medium. In all cases, the plant tissues were placed under the medium in order to limit oxygen availability and minimize bacterial contamination. As soon as hyphae of Phytophthora appeared in the medium, tips of the hyphae were excised and transferred to new plates to avoid contamination.

Production of single zoospore cultures. Single zoospore cultures were obtained following the method of Canaday and Schmitthenner (5). Fifteen 6-mmdiameter pieces from the edges of $P$. sojae colonies growing actively on dilute V8 juice agar were placed in $25 \mathrm{ml}$ of quarterstrength V8 liquid medium $(50 \mathrm{ml}$ of $\mathrm{V} 8$ per liter of water) in petri plates. After 48 $\mathrm{h}$, the culture medium was poured off and replaced with $25 \mathrm{ml}$ of Chen and Zentmyer's salt solution (6) at $\mathrm{pH}$ 7.0. The solution was changed four times at 5-min intervals. The final salt solution was replaced with $20 \mathrm{ml}$ of sterile deionized distilled water, and cultures were incubated under cool-white $40 \mathrm{~W}$ lights at room temperature. Sporangia formed $12 \mathrm{~h}$ after cultures were flooded. Cultures were placed in the refrigerator $\left(4^{\circ} \mathrm{C}\right)$ for $4 \mathrm{~h}$ and then incubated at room temperature. Zoospores appeared within $1 \mathrm{~h}$.

Zoospore concentration was estimated by placing $50 \mu \mathrm{l}$ of each zoospore suspension in micropreparation wells and staining with $25 \mu \mathrm{l}$ of a lacto-phenol Trypan blue solution (27). The number of zoospores in each micropreparation well was counted under a light microscope at $\times 250$. Through serial dilution, the zoospore concentration was adjusted to $1 \times 10^{3}$ per $\mathrm{ml}$ and plated onto quarter-strength V8 agar medium. Selected colonies of germinating zoospores were transferred to new plates to generate 
single-spore cultures. Cultures were stored up to 4 months in slants of dilute V8 agar medium $(40 \mathrm{ml}$ of $\mathrm{V} 8$ juice per liter of water) at $5^{\circ} \mathrm{C}$ until virulence and race tests were performed.

Identification. Two keys, one that groups species of Phytophthora by sporangial characteristics (29) and one that uses other characteristics (20) and other sources $(17,22)$, were used in the identification of Phytophthora isolates. Specific parameters such as host range, growth rate, and oogonal size were used to delineate $P$. sojae from $P$. megasperma (10). An isolate (1819B) of $P$. megasperma from D. H. Scott of Purdue University was used for comparison.

Test for virulence and race determination. Eighty-seven isolates of $P$. sojae were tested for virulence and race determination. The hypocotyl injection method (9) was used to inoculate seedlings of the differential set of soybean cultivars described previously. Sets of 12 seeds of each of the differential cultivars were planted in vermiculite in $27 \times 42 \mathrm{~cm}$ plastic trays in the greenhouse. Inoculum was prepared by growing cultures of the isolates and of previously known races of $P$. sojae on soft dilute V8 agar (9). Six-day-old seedlings were inoculated. After inoculation, plants were covered with clear plastic bags for $12 \mathrm{~h}$ to prevent the agar slurry and the wound from drying. Plants were grown in the greenhouse at $25^{\circ} \mathrm{C}$ in $14 \mathrm{~h}$ of light. Tests were done with three successive sets of 30 isolates each and the known races of $P$. sojae. Each test had five replications, arranged in a completely randomized manner, and was repeated three times. Reactions of the differential cultivars were evaluated 5 days after inoculation. Soybean seedlings with race-specific resistance remained healthy, with either restricted or no lesions. Susceptible seedlings developed large le-

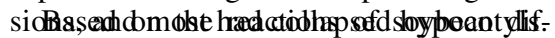
ferentials to known races of $P$. sojae, a differential was considered susceptible if $60 \%$ or more of the seedlings were killed, and resistant if $40 \%$ or less of the seedlings were killed. Intermediate reactions (40 to $60 \%$ ) were not observed.

\section{RESULTS AND DISCUSSION}

Race identification of $P$. sojae. Eightyseven isolates identified as $P$. sojae were characterized for virulence on 13 soybean differentials. Nine isolates were identified as known races $2(1 \mathrm{~b}, 7), 3$ (1a,7), 4 (1a,1c,7), 25 (1a,1b,1c,1k,7), 41 (1a,1b, $1 \mathrm{~d}, 1 \mathrm{k}, 7)$, and 44 (1a,1d,7) (Table 1). Races

Table 2. Isolates of Phytophthora sojae with unique virulence formulae, from diseased soybean plants with Phytophthora root and stem rot symptoms

\begin{tabular}{|c|c|c|}
\hline $\begin{array}{l}\text { No. of Rps genes on which } \\
\text { an isolate was virulent }\end{array}$ & No. of isolates & Virulence formula $^{a}$ \\
\hline 3 & 1 & $1 \mathrm{a}, 1 \mathrm{~b}, 1 \mathrm{k}$ \\
\hline 3 & 4 & $1 \mathrm{a}, 3 \mathrm{c}, 7$ \\
\hline 3 & 1 & $1 \mathrm{a}, 4,7$ \\
\hline 3 & 1 & $1 \mathrm{a}, 5,7$ \\
\hline 4 & 1 & $1 \mathrm{a}, \mathrm{ab}, 3 \mathrm{c}, 7$ \\
\hline 4 & 4 & $1 \mathrm{a}, 1 \mathrm{c}, 3 \mathrm{c}, 7$ \\
\hline 4 & 1 & $1 \mathrm{a}, 2,3 \mathrm{c}, 7$ \\
\hline 5 & 1 & $1 \mathrm{a}, 1 \mathrm{c}, 1 \mathrm{~d}, 3 \mathrm{c}, 7$ \\
\hline 5 & 1 & $1 \mathrm{a}, 2,3 \mathrm{c}, 4,7$ \\
\hline 5 & 1 & $1 \mathrm{a}, 2,3 \mathrm{c}, 5,7$ \\
\hline 5 & 2 & $1 \mathrm{a}, 3 \mathrm{c}, 5,6,7$ \\
\hline 6 & 1 & $1 \mathrm{a}, 1 \mathrm{~b}, 1 \mathrm{c}, 3 \mathrm{~b}, 6,7$ \\
\hline 6 & 1 & $1 \mathrm{a}, 1 \mathrm{c}, 1 \mathrm{~d}, 3 \mathrm{a}, 3 \mathrm{c}, 7$ \\
\hline 6 & 1 & $1 \mathrm{a}, 1 \mathrm{c}, 1 \mathrm{k}, 3 \mathrm{c}, 6,7$ \\
\hline 7 & 1 & $1 \mathrm{a}, 1 \mathrm{~b}, 1 \mathrm{c}, 1 \mathrm{~d}, 1 \mathrm{k}, 5,7$ \\
\hline 7 & 1 & $1 \mathrm{a}, 1 \mathrm{~b}, 1 \mathrm{c}, 2,3 \mathrm{~b}, 5,7$ \\
\hline 7 & 2 & $1 \mathrm{a}, 1 \mathrm{c}, 1 \mathrm{~d}, 2,3 \mathrm{c}, 4,7$ \\
\hline 7 & 1 & $1 \mathrm{a}, 1 \mathrm{c}, 1 \mathrm{~d}, 3 \mathrm{c}, 4,5,7$ \\
\hline 7 & 1 & $1 \mathrm{a}, 1 \mathrm{~b}, 2,3 \mathrm{a}, 5,6,7$ \\
\hline 7 & 1 & $1 \mathrm{a}, 1 \mathrm{c}, 2,3 \mathrm{a}, 3 \mathrm{~b}, 5,7$ \\
\hline 7 & 1 & $1 \mathrm{a}, 1 \mathrm{~d}, 1 \mathrm{k}, 3 \mathrm{c}, 4,5,6$ \\
\hline 7 & 1 & $2,3 \mathrm{a}, 3 \mathrm{c}, 4,5,6,7$ \\
\hline 8 & 1 & $1 \mathrm{a}, 1 \mathrm{~b}, 1 \mathrm{~d}, 1 \mathrm{k}, 3 \mathrm{a}, 3 \mathrm{~b}, 3 \mathrm{c}, 7$ \\
\hline 8 & 1 & $1 \mathrm{a}, 1 \mathrm{c}, 1 \mathrm{~d}, 1 \mathrm{k}, 3 \mathrm{c}, 5,6,7$ \\
\hline 8 & 1 & $1 \mathrm{a}, 1 \mathrm{~d}, 1 \mathrm{k}, 2,3 \mathrm{c}, 4,5,7$ \\
\hline 8 & 1 & $1 \mathrm{a}, 1 \mathrm{c}, 1 \mathrm{k}, 2,3 \mathrm{a}, 4,5,7$ \\
\hline 8 & 3 & $1 \mathrm{a}, 1 \mathrm{c}, 1 \mathrm{~d}, 2,3 \mathrm{c}, 4,5,7$ \\
\hline 8 & 1 & $1 \mathrm{a}, 1 \mathrm{c}, 1 \mathrm{~d}, 2,3 \mathrm{c}, 5,6,7$ \\
\hline 8 & 1 & $1 \mathrm{a}, 1 \mathrm{c}, 2,3 \mathrm{c}, 4,5,6,7$ \\
\hline 8 & 1 & $1 \mathrm{a}, 2,3 \mathrm{a}, 3 \mathrm{c}, 4,5,6,7$ \\
\hline 8 & 1 & $1 \mathrm{a}, 1 \mathrm{c}, 1 \mathrm{~d}, 3 \mathrm{c}, 4,5,6,7$ \\
\hline 9 & 1 & $1 \mathrm{a}, 1 \mathrm{~b}, 1 \mathrm{~d}, 1 \mathrm{k}, 3 \mathrm{a}, 3 \mathrm{c}, 5,6,7$ \\
\hline 9 & 1 & $1 \mathrm{a}, 1 \mathrm{~b}, 1 \mathrm{c}, 1 \mathrm{~d}, 1 \mathrm{k}, 2,3 \mathrm{a}, 3 \mathrm{~b}, 7$ \\
\hline 9 & 2 & $1 \mathrm{a}, 1 \mathrm{~b}, 1 \mathrm{~d}, 2,3 \mathrm{a}, 3 \mathrm{c}, 5,6,7$ \\
\hline 9 & 1 & $1 \mathrm{a}, 1 \mathrm{c}, 1 \mathrm{~d}, 1 \mathrm{k}, 3 \mathrm{c}, 4,5,6,7$ \\
\hline 9 & 2 & $1 \mathrm{a}, 1 \mathrm{c}, 1 \mathrm{~d}, 1 \mathrm{k}, 2,3 \mathrm{c}, 4,5,7$ \\
\hline 9 & 2 & $1 \mathrm{a}, 1 \mathrm{c}, 1 \mathrm{~d}, 2,3 \mathrm{c}, 4,5,6,7$ \\
\hline 9 & 1 & $1 \mathrm{a}, 2,3 \mathrm{a}, 3 \mathrm{~b}, 3 \mathrm{c}, 4,5,6,7$ \\
\hline 9 & 1 & $1 \mathrm{a}, 1 \mathrm{~d}, 2,3 \mathrm{a}, 3 \mathrm{c}, 4,5,6,7$ \\
\hline 10 & 1 & $1 \mathrm{a}, 1 \mathrm{~b}, 1 \mathrm{c}, 1 \mathrm{~d}, 1 \mathrm{k}, 2,3 \mathrm{a}, 3 \mathrm{c}, 6,7$ \\
\hline 10 & 1 & $1 \mathrm{a}, 1 \mathrm{~b}, 1 \mathrm{c}, 1 \mathrm{~d}, 1 \mathrm{k}, 3 \mathrm{c}, 4,5,6,7$ \\
\hline 10 & 1 & $1 \mathrm{a}, 1 \mathrm{~b}, 1 \mathrm{~d}, 1 \mathrm{k}, 2,3 \mathrm{c}, 4,5,6,7$ \\
\hline 10 & 1 & $1 \mathrm{a}, 1 \mathrm{c}, 1 \mathrm{~d}, 1 \mathrm{k}, 2,3 \mathrm{c}, 4,5,6,7$ \\
\hline 11 & 1 & $1 \mathrm{a}, 1 \mathrm{~b}, 1 \mathrm{~d}, 1 \mathrm{k}, 2,3 \mathrm{~b}, 3 \mathrm{c}, 4,5,6,7$ \\
\hline 11 & 1 & $1 \mathrm{a}, 1 \mathrm{~b}, 1 \mathrm{c}, 1 \mathrm{~d}, 1 \mathrm{k}, 3 \mathrm{~b}, 3 \mathrm{c}, 4,5,6,7$ \\
\hline 11 & 1 & $1 \mathrm{a}, 1 \mathrm{~b}, 1 \mathrm{c}, 1 \mathrm{~d}, 2,3 \mathrm{a}, 3 \mathrm{~b}, 4,5,6,7$ \\
\hline 11 & 1 & $1 \mathrm{a}, 1 \mathrm{c}, 1 \mathrm{~d}, 1 \mathrm{k}, 2,3 \mathrm{a}, 3 \mathrm{~b}, 3 \mathrm{c}, 4,5,7$ \\
\hline 11 & 1 & $1 \mathrm{a}, 1 \mathrm{c}, 1 \mathrm{~d}, 1 \mathrm{k}, 2,3 \mathrm{a}, 3 \mathrm{c}, 4,5,6,7$ \\
\hline 12 & 1 & $1 \mathrm{a}, 1 \mathrm{~b}, 1 \mathrm{c}, 1 \mathrm{~d}, 1 \mathrm{k}, 2,3 \mathrm{a}, 3 \mathrm{c}, 4,5,6,7$ \\
\hline 12 & 5 & $1 \mathrm{a}, 1 \mathrm{~b}, 1 \mathrm{~d}, 1 \mathrm{k}, 2,3 \mathrm{a}, 3 \mathrm{~b}, 3 \mathrm{c}, 4,5,6,7$ \\
\hline 13 & 2 & $1 \mathrm{a}, 1 \mathrm{~b}, 1 \mathrm{c}, 1 \mathrm{~d}, 1 \mathrm{k}, 2,3 \mathrm{a}, 3 \mathrm{~b}, 3 \mathrm{c}, 4,5,6,7$ \\
\hline
\end{tabular}

${ }^{a}$ List of ineffective Rps genes and alleles.

Table 1. Races of Phytophthora sojae identified among isolates obtained from diseased soybean plants in Michigan soybean fields over the 1993 to 1997 growing seasons

\begin{tabular}{|c|c|c|c|c|c|c|c|c|}
\hline \multirow[b]{2}{*}{ Race } & \multirow[b]{2}{*}{ Virulence formula ${ }^{a}$} & \multicolumn{6}{|c|}{ Rps genes and alleles } & \multirow[b]{2}{*}{ No. identified } \\
\hline & & $1 \mathbf{a}$ & $1 b$ & 1c & 1d & $1 \mathbf{k}$ & 7 & \\
\hline 2 & $1 b, 7$ & & $\mathrm{~S}$ & & & & $\mathrm{~S}$ & 1 \\
\hline 3 & $1 \mathrm{a}, 7$ & $\mathrm{~S}^{\mathrm{b}}$ & & & & & $\mathrm{S}$ & 2 \\
\hline 4 & $1 \mathrm{a}, 1 \mathrm{c}, 7$ & $\mathrm{~S}$ & & $\mathrm{~S}$ & & & $\mathrm{~S}$ & 2 \\
\hline 25 & $1 \mathrm{a}, 1 \mathrm{~b}, 1 \mathrm{c}, 1 \mathrm{k}, 7$ & $\mathrm{~S}$ & $\mathrm{~S}$ & $\mathrm{~S}$ & & $\mathrm{~S}$ & $\mathrm{~S}$ & 2 \\
\hline 41 & $1 \mathrm{a}, 1 \mathrm{~b}, 1 \mathrm{~d}, 1 \mathrm{k}, 7$ & $\mathrm{~S}$ & $\mathrm{~S}$ & & $\mathrm{~S}$ & S & $\mathrm{S}$ & 1 \\
\hline 44 & $1 \mathrm{a}, 1 \mathrm{~d}, 7$ & $\mathrm{~S}$ & & & $\mathrm{~S}$ & & $\mathrm{~S}$ & 1 \\
\hline
\end{tabular}

a Ineffective Rps genes and alleles (1a, 1b, 1c, 1d, 1k, 7).

b $60 \%$ or more of hypocotyl inoculated seedlings were killed. 
3 and 4 were previously identified in Michigan (15), and races 2, 25, 41, and 44 are reported for the first time in Michigan. Sixty-nine isolates had virulence reactions that did not match those of currently known races of $P$. sojae $(1,2,4,13,24)$ (Table 2). Two isolates were pathogenic on all of the soybean differentials. Nine isolates incited disease in $40 \%$ or less of the seedlings of each soybean differential, including cv. Williams ( $r p s$ ), and were classified nonpathogenic.

Although the hypocotyl injection test may bypass some natural defense mechanisms that have been described as field tolerance (19), all isolates tested on the differentials were isolated from soybean plants with symptoms of Phytophthora root and stem rot. This suggests a broad range of $P$. sojae virulence capable of causing disease on soybean in Michigan.

Reaction of soybean differentials to isolates of $\boldsymbol{P}$. sojae. RPX-146-36 (Rps 3b), L83-570 (Rps 3a), Harosoy 13XX (Rps 1b), Williams 82 (Rps $1 \mathrm{k}$ ), and Harosoy 62XX (Rps 6) were resistant to 81, 77, 74, 69 , and $66 \%$ of the isolates, respectively (Table 3). According to the 2000 Michigan Soybean Performance Report (7), Rps genes 1a, 1c, 1k, 3, 6, and 7 are incorporated either singly or in combinations $(1 b+3,1 c+3$, and $1 k+6)$ in many cultivars currently planted in Michigan. Previously, these genes were reported to convey resistance against most of the currently known races of $P$. sojae. In this study, Rps 1a and 7 were resistant to only 12 and $13 \%$ of the isolates (Table 3). This may be the result of long-term use of these genes in the state. Incorporating Rps 3b, 3a, 1b, 1k, and 6 singly or in combinations in soybean cultivars should provide improved genetic protection against most of the races present in Michigan soybean fields and minimize the risk of yield loss. Due to race shifts, however, and the presence of rare but compatible races of the pathogen, virulence has

Table 3. Ranked responses of Rps genes and alleles to virulent isolates of Phytophthora sojae from soybean plants with Phytophthora root and stem rot symptoms

\begin{tabular}{llc}
\hline Gene $^{\mathbf{a}}$ & Cultivar & $\begin{array}{c}\text { \% isolates non- } \\
\text { pathogenic on cv. }\end{array}$ \\
\hline Rps 3b & PRX 146-36 & 81 \\
RPS 3a & L83-570 & 77 \\
Rps 1b & Harosoy 13xx & 74 \\
Rps 1k & Williams 82 & 69 \\
Rps 6 & Harosoy 62xx & 66 \\
Rps 2 & L76-1988 & 61 \\
Rps 4 & L85-2352 & 60 \\
Rps 5 & L85-3059 & 55 \\
Rps 1c & Williams 79 & 54 \\
Rps 1d & PI 103 & 54 \\
Rps 3c & PRx145-48 & 45 \\
Rps 1a & Harlon & 22 \\
Rps 7 & Harosoy & 21 \\
rps & Williams & 0 \\
\hline
\end{tabular}

a $r p s$ is susceptible; Rps indicates resistance.

$\mathrm{b} \%$ of virulent isolates. been known to increase and result in disease within 8 years of continued deployment of cultivars with a narrow line of genetic defense (18). Because of this risk, non-race-specific genetic protection in soybeans against $P$. sojae $(19,21,26)$ has become more attractive, particularly when deployed as part of an IPM program. Using soybean lines with both field tolerance and genes conferring resistance to the majority of virulent races of $P$. sojae that are common in the state may be beneficial due to the difficulty of predicting weather conditions conducive to Phytophthora root rot and the broad range of virulence of $P$. sojae observed in this study. Highly variable and virulent pathotypes of $P$. sojae have been reported elsewhere. Henry and Kirkpatrick (11) reported an isolate of $P$. sojae that was pathogenic on all eight soybean differentials tested. Hobe and Schmitthenner (12) isolated previously uncharacterized pathotypes of $P$. sojae directly from soil, suggesting the existence of a large diversity of virulence in $P$. sojae populations. Since outcrossing (in addition to clonal evolution) appears to produce new races in $P$. sojae $(3,8,14,16)$, Forster et al. (8) predicted that a very large number of $P$. sojae races eventually would be identified. The virulence diversity exhibited by the isolates in this study lends support to this prediction. It is possible, therefore, that a large number of $P$. sojae races or the appearance of novel pathotypes as observed in this work may in the future make ineffective the Rps genes currently used to protect soybeans from Phytophthora root and stem rot. Therefore, it is necessary to intensify the search for new genes for resistance to Phytophthora root rot, to increase use of other control tactics, and to understand the mechanisms involved in the soybeanPhytophthora pathosystem. Nevertheless, incorporating Rps 1b, 1k, 3a, 3b, and 6 in soybean cultivars with good field tolerance, and in conjunction with other control measures, should provide improved protection of soybeans from Phytophthora root and stem rot.

\section{ACKNOWLEDGMENTS}

This research was supported in part by the Michigan Agricultural Experiment Station and by grants from the NC Soybean Research Program and the Michigan Soybean Promotion Committee. We would also like to thank A. F. Schmitthenner for allowing us to learn his race identification techniques in his laboratory.

\section{LITERATURE CITED}

1. Abney, T. S., Melgar, J. C., Richards, T. L., Scott, D. H., Grogan, J., and Young, J. 1997. New races of Phytophthora sojae with Rps1-d virulence. Plant Dis.81:653-655.

2. Athow, K. L. 1987. Fungal diseases. Pages 687-727 in: Soybeans: Improvement, Production and Uses. J. R. Wilcox, ed. American Society of Agronomy, Madison, WI.

3. Bhat, R. G., and Schmitthenner, A. F. 1993. Genetic crosses between physiologic races of Phytophthora sojae. Exp. Mycol. 17:122-129.

4. Buzzell, R. I., and Anderson, T. R. 1992.
Inheritance and race reaction of a new soybean Rps 1 allele. Plant Dis. 76:600-601.

5. Canaday, C. H., and Schmitthenner, A. F. 1982. Isolating Phytophthora megasperma f. sp. glycinea from soil with a baiting method that minimizes Pythium contamination. Soil Biol. Biochem. 14:6768.

6. Chen, D. W., and Zentmyer, G. A. 1970 Production of sporangia of Phytophthora cinnamomi in axenic culture. Mycologia 62:397402.

7. Diers, B. W., and Boyse, F. J. 1997. 1997 Michigan soybean performance report. Michigan Soybean Promotion Committee, Frankenmuth, MI.

8. Forster, H., Tyler, B. M., and Coffey, M. D. 1994. Phytophthora sojae races have arisen by clonal evolution and by rare outcrosses. Mol. Plant-Microbe Interact. 7:780-791.

9. Haas, J. H., and Buzzell, R. I. 1976. New races 5 and 6 of Phytophthora megasperma var. sojae and different reactions of soybean cultivars for races 1 to 6. Phytopathology 66:1361-1362.

10. Hansen, E. M., and Maxwell, D. P. 1991. Species of the Phytophthora megasperma complex. Mycologia 83:376-381.

11. Henry, R. N., and Kirkpatrick, T. L. 1995. Two new races of Phytophthora sojae, causal agent of Phytophthora root and stem rot of soybean, identified from Arkansas soybean fields. Plant Dis. 79:1074.

12. Hobe, M. A., and Schmitthenner, A. F. 1981. Direct isolation of new races of Phytophthora megasperma var. sojae from NW Ohio soils. (Abstr.) Phytopathology 71:226.

13. Layton, A. C., Athow, K. L., and Laviolette, F. A. 1986. A new physiologic race of Phytophthora megasperma f. sp. glycinea. Plant Dis. 70:500-501.

14. Layton, A. C., and Kuhn, D. N. 1990. In planta formation of heterokaryons of Phytophthora megasperma f. sp. glycinea. Phytopathology 80:602-606.

15. Lockwood, J. L., and Chen, S. D. 1978. Race determination of Phytophthora megasperma var. sojae using differential soybean varieties inoculated with zoospores or incubated on flooded soil samples. Plant Dis. 62:16871690.

16. Long, M., and Keen, N. T. 1977. Genetic evidence for diploidy in Phytophthora megasperma var. sojae. Phytopathology 67:675-677.

17. Margulis, L., Corliss, J. O., Melkonian, M., and Chapman, D. J. 1989. Handbook of Protoctista. Jones and Barlett, Boston.

18. McBlain, B. A., and Schmitthenner, A. F. 1991. Evaluation of recurrent selection for Phytophthora tolerance in soybean. Ohio Agricultural Research and Extension Center Bull. 1187. Ohio Agricultural Research and Development Center, Wooster.

19. Mussell, H. 1980. Tolerance to disease. Pages 39-52 in: Plant Disease: An Advance Treatise, Vol. V. J. G. Horsfall and E. B. Cowling, eds. Academic Press, New York.

20. Newhook, F. J., Waterhouse, G. M., and Stamps, D. J. 1978. Tabular key to the species of Phytophthora. Mycological Pap. 143. Commonw. Mycol. Inst., Kew, Surrey, England.

21. Olah, A. F., and Schmitthenner, A. F. 1985. Glyceolin accumulation in soybean lines tolerant to Phytophthora megasperma f. sp. glycinea. Phytopathology 75:542-546.

22. Patterson, D. J., and Sogin, M. L. 1992. Eukaryotic Origins and Protistan Diversity. Pages 13-46 in: The Origin and Evolution of the Cell. H. Harman and K. Matsuno, eds. World Scientific, Singapore.

23. Schmitthenner, A. F. 1985. Problems and progress in control of Phytophthora root rot of 
soybean. Plant Dis. 69:362-368.

24. Schmitthenner, A. F., Hobe, M., and Bhat, R. G. 1994. Phytophthora sojae races in Ohio over a 10-year interval. Plant Dis. 78:269276.

25. Schmitthenner, A. F., and Van Doren, D. M., Jr. 1985. Integrated control of root rot of soybean caused by Phytophthora megasperma f. sp. glycinea. Pages 263-266 in: Ecology and Management of Soilborne Plant Pathogens. C. A. Parker, A. D. Rovira, K. J. Morre, and P. T.
W. Wong, eds. American Phytopathological Society, St. Paul, MN.

26. Schmitthenner, A. F., and Walker, A. K. 1979. Tolerance versus resistance for the control of Phytophthora root rot in soybeans. Proc. Soybean Seed Res. Conf., 19th. H. D. Loden and

D. Wilkinson, eds. American Trade Association, Washington, DC.

27. Vedenyapina, E. G., Safir, G. R., Niemira, B. A., and Chase, T. E. 1996. Low concentrations of the isoflavone genistein influence in vitro asexual reproduction and growth of $P h y-$ tophthora sojae. Phytopathology 86:144-148.

28. Ward, E. W. B. 1990. The interaction of soybeans with Phytophthora megasperma f. sp. glycinea: Pathogenicity. Pages 311-327 in Biological Control of Soilborne Plant Pathogens. B. Hornby, ed. C.A.B. International, Wallingford, England.

29. Waterhouse, G. M. 1963. Key to the species of Phytophthora de Bary. Commonw. Mycol. Inst., Kew, Surrey, England. 